\title{
The Effect of Liquidity and Working Capital Turnover on Profitability at PT. Sumber Cipta Multiniaga, South Jakarta
}

\author{
Jasmani \\ Universitas Pamulang \\ E-mail: djasmany@yahoo.com
}

(Received: February-2019; Reviewed: April-2019; Accepted: Juni-2019;

Avalaibel Online: July-2019; Published: September-2019)

(3) This is an open access article distributed under the Creative Commons Attribution License CC-BY-NC-4.0 C2019 by author (https://creativecommons.org/licenses/by-nc/4.0/)

\begin{abstract}
The logical consequence of credit sales is the increase in trade receivables which in turn disrupts the company's liquidity. This study aims to determine the effect between liquidity and working capital turnover on profitability at PT. Sumber Cipta Multiniaga. The method uses survey techniques and saturated sampling in the form of financial statements. The analytical tool used is descriptive and verification analysis with assumptions with statistical analysis in the form of regression tests, correlation coefficient tests, determination coefficient tests and hypothesis tests. The results of the current ratio study have a significant effect on the determination of $32.6 \%$. Hypothesis testing obtained $\rho$ value $0,000<0.05$. Working capital turnover has a significant effect on return on assets, with a determination of $29.6 \%$. Hypothesis testing obtained $\rho$ value $0,000<0.05$. The current ratio and Working capital turnover simultaneously have a significant effect on the return on assets with a determination of $49.2 \%$. Hypothesis testing obtained $\rho$ value $0,000<0.05$.
\end{abstract}

Keywords: Current ratio; working capital turnover; return on asset.

\section{INTRODUCTION}

Business competition in the industry today is so tight, not least in the communications industry (Rengifurwarin, Akib, \& Salam, 2018). Various companies offer various facilities to use products produced by a particular company, the condition triggers competition between companies in the industry (Hasibuan, 1993; Tambunan, T, \& Arus, 2004; Utomo, 2011). One of the sales programs delivered by several products is the term of payment in order to have certain products, including products produced by PT Sumber Cipta Multiniaga, South Jakarta. The method of payment offered is by installments of certain products, without interest in order to increase sales volume (Gunawan \& Linawati, 2013; Heryono \& Kardianawati, 2018; Hutapea $\&$ Muningsih, 2017). The logical consequence of credit sales is the increase in trade receivables which in turn disrupts the company's liquidity, disruption of this liquidity, will affect the fulfillment of obligations both obligations to internal parties and obligations to external parties 
(Faisal, Samben, \& Pattisahusiwa, 2018; Mulyanti \& Supriyani, 2018; Putri \& Merkusiwati, 2014; Surya, Ruliana, \& Soetama, 2017). This is, of course, related to the activities carried out by companies that require liquidity both for operational / production activities and investment financing (capital expenditure). Adequacy of liquidity is important as a support for the program to increase sales volume. Increased sales volume will improve many things, but not limited to improvements in quality or volume of production, increased market share, consumer confidence or creditors, which in turn improves performance including profitability (Sunarsi, 2017, 2018a, 2018b).

Ideally, capital is sufficient to meet production / operating needs for a certain period of time as referred to in the Work Plan and Corporate Budget (RKAP), which are commonly used. In general, the importance of working capital for companies, especially for the financial health of the company, namely: 1) The activities of a financial manager are more spent in the company's operational activities from time to time. 2) Investment in current assets is fast and often changes frequently and tends to be volatile. While current assets are the company's working capital, meaning that the change will affect working capital. Therefore, it needs serious attention from the financial manager. 3) In practice, it is often that half of the total assets are part of current assets, which is the company's working capital. 4) For companies that are relatively small, relatively limited to enter the market with large capital and long term. Corporate funding relies more on short-term debt, such as trade debt, one-year bank debt which can certainly affect working capital. 5) There is a very close relationship between sales growth and working capital requirements. The increase in sales was related to receivables, inventories, and cash. And vice versa if there is a decline in sales, will affect the components in the current assets (Kasmir, 2014a, 2014b).

Working capital turnover starts when cash is invested in the working capital component until it returns to cash. The shorter the working capital turnover period, the faster the working capital turnover so that the working capital turnover is higher and the company is more efficient which ultimately increases profitability (Baskara, 2013; Horne, J.C. dan Wachowicz, 2007; Siamat, 2005). Likewise, when a low working capital turnover shows an excess of working capital that might be caused by low inventory turnover, accounts receivable or too much cash balance. Vice versa if the working capital turnover is high, it is possible that high inventory turnover, accounts receivable turnover or cash balances are too small.

Working capital can be interpreted as an excess of current assets over short-term debt (Brigham \& Houston, 2013; Ekawati, 2014; Faisal et al., 2018; Syaifuddin, 2008). This excess comes from long-term debt and own capital, called net working capital. The ability of a company to pay so much that it is able to fulfill all financial obligations that must be fulfilled immediately, it can be said that the company is called liquid and vice versa, if the company does not have the ability to pay, is called liquid. When it is associated with the company's normal operating cycle, which includes the purchase-sales-billing cycle. Liquidity is one of the factors that determine the success or failure of the company's financial management (Habibah, 2015; Indradi, 2018; Lestari \& Tanuatmodjo, 2016; Maulida, Moehaditoyo, \& Nugroho, 2018). The amount of payment instruments owned by the company is a source of strength for the company to pay obligations that must be paid. The higher the liquidity, the better the company's position in the eyes of creditors, but on the other hand there is a significant opportunity cost. This means, if the company decides to set a large amount of working capital, it is likely that the level of liquidity will be maintained but the opportunity to earn profits will decrease which will ultimately have an impact on the decline in profitability, on the contrary, if the company wants to maximize profitability, it might be able to affect the level of company liquidity.

Profitability is the end result of a number of policies and decisions made by the company (Arimi \& Mahfud, 2012; Butar \& Sudarsi, 2012; Setiadewi \& Purbawangsa, 2015; Surya et al., 
2017; Yusra, 2016). Profitability can provide useful clues in assessing the effectiveness of a company's operations, so that profitability ratios will designate a combination of the effects of liquidity, asset management, and debt on operating results. Profitability will show the balance of revenue and the company's ability to generate profits at various levels of operations, so this ratio will reflect the effectiveness and success of the overall management (Gemilang, 2017; Kurnianingsih, 2013; Kusumawardhani, 2018; Ramona, 2017). With the continued increase in consumer demand for communication tools, each company needs to have adequate managerial skills, so that the company is run is able to compete with companies in the industry. Every company must have a strategy to increase sales, so that the products sold are able to attract consumer interest in order to increase product sales, with increased sales of products produced, the company's profitability will also increase. Increasing profitability can reflect the success of management in running a company.

\section{METHOD}

The study was conducted at PT. Sumber Cipta Multiniaga South Jakarta. According to (Sugiyono, 2016) defining population is the number of generalization areas consisting of objects or subjects that have the quality and characteristics determined by the researcher and then conclusions are drawn. The population in this study is the financial statements of PT. Sumber Cipta Multiniaga South Jakarta. Suharsini (Suharsimi, 2013)argues that "The sample is part or representative of the population under study. In this study, the sample used is the financial statements of PT. Sumber Cipta Multiniaga South Jakarta. Data collection methods used are documentation, surveys, and literature studies. The data analysis method used is the classic assumption test consisting of a normality test, multicollinearity test, autocorrelation test, and heteroscedasticity test. Descriptive and verification analysis used is descriptive analysis, verification analysis, multiple regression analysis, coefficient of determination analysis and hypothesis testing.

\section{RESULT AND DISCUSSION}

The trust of various parties to the company is the company's main capital in achieving the targets set, the company's inability to pay its obligations, especially short-term debt that is due.

\section{Classic assumption test}

A normality test is done to test whether, in the regression model, the dependent variable and the independent variable are normally distributed or not normally distributed. The results of the normality test with the Kolmogorov-Smirnov Test are as follows:

Table 1:

Results of Kolmogorov-Smirnov normality

Tests of Normality

\begin{tabular}{lr|r|r|r|r|r}
\hline & \multicolumn{3}{c}{ Kolmogorov-Smirnov } & \multicolumn{3}{c}{ Shapiro-Wilk } \\
& Statistic & df & Sig. & Statistic & df & Sig. \\
\hline Return on Asset $(\mathrm{Y})$ & .083 & 36 & $.200^{*}$ & .968 & 36 & .362 \\
\hline
\end{tabular}

Based on the test results in the table above obtained significance value $\alpha=0.200$ where the value is greater than the value of $\alpha=0.050$ or $(0.076>0.05)$. Thus, the assumption of the distribution of equations in this test is normal. 
Multicollinearity test is done by looking at the value of the tolerance Value and Variance Inflation Factor (VIF). The test results are as follows:

Table 2.

Multicollinearity Test Results with Collinierity Statistics.

\section{Coefficients $^{\mathrm{a}}$}

\begin{tabular}{|c|c|c|c|c|c|c|c|}
\hline \multirow[b]{2}{*}{ Model } & \multicolumn{2}{|c|}{$\begin{array}{l}\text { Unstandardized } \\
\text { Coefficients }\end{array}$} & \multirow{2}{*}{$\begin{array}{c}\text { Standardized } \\
\text { Coefficients } \\
\text { Beta } \\
\end{array}$} & \multirow[b]{2}{*}{$\mathrm{t}$} & \multirow[b]{2}{*}{ Sig. } & \multicolumn{2}{|c|}{ Collinearity Statistics } \\
\hline & B & $\begin{array}{l}\text { Std. } \\
\text { Error }\end{array}$ & & & & Tolerance & VIF \\
\hline $1 \quad$ (Constant) & 9.046 & 9.495 & & .953 & .348 & & \\
\hline Current Ratio (X1) & .740 & .208 & .459 & 3.565 & .001 & .930 & 1.076 \\
\hline Working Capital Turnover (X2) & .446 & .136 & .422 & 3.279 & .002 & .930 & 1.076 \\
\hline
\end{tabular}

Based on the test results in the table above the tolerance value of each independent variable is $0.930<1.0$ and the Variance Inflation Factor (VIF) value is $1.076<10$, thus this regression model does not occur multicollinearity.

Testing is done with the Darbin-Watson test (DW test). The test results are as follows:

Table 3.

Autocorrelation Test Results

\begin{tabular}{llrrrrr}
\multicolumn{7}{c}{ Model Summary $^{\mathbf{b}}$} \\
\hline Model & $\mathrm{R}$ & R Square & $\begin{array}{c}\text { Adjusted R } \\
\text { Square }\end{array}$ & $\begin{array}{c}\text { Std. Error of } \\
\text { the Estimate }\end{array}$ & Durbin-Watson \\
\hline 1 & $.701^{\mathrm{a}}$ & .492 & .461 & 3.682 & 2.415 \\
\hline
\end{tabular}

The test results in the table above obtained the value of Durbin-Watson of 2,415 that value is between the intervals of $1,550-2,460$. Thus the regression model stated no autocorrelation disorders.

Heteroscedasticity testing is intended to test whether in a regression model residual variance inequality occurs. The test results are as follows:

Table 4.

Heteroskedasticity Test Results with the Glejser Test Model

\section{Coefficients}

\begin{tabular}{|c|c|c|c|c|c|c|}
\hline \multirow{2}{*}{\multicolumn{2}{|c|}{ Model }} & \multicolumn{2}{|c|}{$\begin{array}{c}\text { Unstandardized } \\
\text { Coefficients }\end{array}$} & \multirow{2}{*}{$\begin{array}{c}\text { Standardized } \\
\text { Coefficients } \\
\text { Beta } \\
\end{array}$} & \multirow[b]{2}{*}{$\mathrm{t}$} & \multirow[b]{2}{*}{ Sig. } \\
\hline & & B & Std. Error & & & \\
\hline \multirow[t]{3}{*}{1} & (Constant) & 1.364 & 6.011 & & .227 & .822 \\
\hline & Current Ratio (X1) & .059 & .131 & .080 & .446 & .659 \\
\hline & $\begin{array}{l}\text { Working Capital } \\
\text { Turnover (X2) }\end{array}$ & -.018 & .086 & -.037 & -.205 & .839 \\
\hline
\end{tabular}

The test results using the glacier test obtained Sig. 0.659 and $0.839>0.05$. Therefore, the regression model does not have heteroscedasticity disorder.

\section{Descriptive Analysis}

Descriptive analysis using SPSS has shown the minimum score, highest score, Mean, and Standard Deviation of each variable. The table below is the result of computational calculation, as follows: 
Table 5.

Results of Descriptive Statistics Testing

\begin{tabular}{lr|r|r|r|r}
\hline \multicolumn{7}{c}{ Descriptive Statistics } \\
\hline & N & \multicolumn{1}{c}{ Minimum } & Maximum & Mean & \multicolumn{1}{c}{ Std. Deviation } \\
\hline Current Ratio (X1) & 36 & 34 & 45 & 39.54 & 3.108 \\
\hline $\begin{array}{l}\text { Working Capital } \\
\text { Turnover (X2) }\end{array}$ & 36 & 43 & 65 & 54.31 & 4.748 \\
\hline Return on Asset (Y) & 36 & 54 & 72 & 62.53 & 5.014 \\
\hline Valid N (listwise) & 36 & & & & \\
\hline
\end{tabular}

Based on the results in the table above the current ratio variable obtained a minimum growth percentage of 34 and a maximum growth percentage obtained of 45 , a mean of 39.54 and a standard deviation of 3.108 .

Working capital turnover variable obtained a minimum growth percentage of 43 and a maximum growth percentage obtained of 65 , a mean of 54.31 and a standard deviation of 4.748 . The return on asset variable is obtained a minimum growth percentage of 54 and a maximum growth percentage obtained by 72 , a mean of 62.53 and a standard deviation of 5.014.

\section{Multiple Linear Regression Analysis}

Multiple regression analysis is intended to determine how much influence the variable Current ratio (X1) and Working capital turnover (X2 on Return on assets (Y).

Table 6.

Results of Multiple Linear Regression Tests

\begin{tabular}{|c|c|c|c|c|c|}
\hline \multirow[b]{3}{*}{ Model } & \multicolumn{5}{|c|}{ Coefficients $^{\mathbf{a}}$} \\
\hline & \multicolumn{2}{|c|}{$\begin{array}{c}\text { Unstandardized } \\
\text { Coefficients }\end{array}$} & \multirow{2}{*}{$\begin{array}{l}\text { Standardized } \\
\text { Coefficients } \\
\text { Beta }\end{array}$} & \multirow[b]{2}{*}{$\mathrm{t}$} & \multirow[b]{2}{*}{ Sig. } \\
\hline & B & Std. Error & & & \\
\hline $1 \quad$ (Constant) & 9.046 & 9.495 & & .953 & .348 \\
\hline Current Ratio (X1) & .740 & .208 & .459 & 3.565 & .001 \\
\hline Working Capital Turnover (X2) & .446 & .136 & .422 & 3.279 & .002 \\
\hline
\end{tabular}

Based on the calculation results in the above table can be presented in the form of standardized regression equation as follows: $\mathrm{Y}=9,046+0.740 \mathrm{X} 1+0.446 \mathrm{X} 2$. The equation can be explained as follows:

Constant value is obtained at 9,046, stating that without being influenced by the variable Current ratio and Working capital turnover the amount of Return on assets has been formed at 9,046 points. The current ratio (X1) has a positive and significant effect on Return on assets (Y) with a coefficient value of 0.740 . This means that if the Current ratio (X1) variable increases by one unit assuming the Working capital turnover (X2) variable is constant or constant (0), then return on assets $(\mathrm{Y})$ will also increase by 0.740 points. Working capital turnover $(\mathrm{X} 2)$ has a positive and significant effect on Return on Assets (Y) with a coefficient value of 0.446 . This means that if Working capital turnover (X2) increases by one unit assuming the variable Current ratio (X1) is constant, then Return on assets (Y) will also increase by 0.446 points.

\section{Correlation Coefficient Analysis}

The correlation coefficient is used to determine the level of influence strength of the independent variables on the dependent variable. 
Table 7.

Test Results for Current Ratio Correlation Coefficients Against Return on Assets

\begin{tabular}{llr|r}
\multicolumn{4}{c}{ Correlations $^{\mathbf{b}}$} \\
\hline & $\begin{array}{c}\text { Current } \\
\text { Ratio (X1) }\end{array}$ & $\begin{array}{r}\text { Return on Asset } \\
(\mathrm{Y})\end{array}$ \\
\hline Current Ratio (X1) & Pearson Correlation & 1 & $.571^{\text {*** }}$ \\
\cline { 2 - 4 } & Sig. (2-tailed) & & .000 \\
\hline Return on Asset (Y) & Pearson Correlation & $.571^{* *}$ & 1 \\
\cline { 2 - 4 } & Sig. (2-tailed) & .000 & \\
\hline
\end{tabular}

An obtained a correlation value of 0.571. means that the Current ratio (X1) partially has a moderate level of influence on Return on assets (Y).

Table 8.

Correlation Coefficient Test Results Working capital turnover Against Return on assets

\begin{tabular}{llrr}
\hline \multicolumn{1}{c}{ Correlations $^{\mathbf{b}}$} \\
& \multicolumn{1}{c}{$\begin{array}{r}\text { Working Capital } \\
\text { Turnover (X2) }\end{array}$} & $\begin{array}{r}\text { Return on } \\
\text { Asset (Y) }\end{array}$ \\
\hline $\begin{array}{l}\text { Working Capital Turnover } \\
\text { (X2) }\end{array}$ & Pearson Correlation & 1 & $.544^{* *}$ \\
\cline { 2 - 4 } Return on Asset (Y) & Sig. (2-tailed) & .001 \\
& Pearson Correlation & $.544^{* *}$ & 1 \\
\cline { 2 - 4 } & Sig. (2-tailed) & .001 & \\
\hline
\end{tabular}

The results in the table above obtained a correlation value of 0.544 . This shows that the Working capital turnover (X2) variable partially has a strong degree of influence on Return on assets (Y).

Table 9.

Correlation Coefficient Test Results Current Ratio and Working Capital Turnover together Against Return on Assets

\begin{tabular}{lr|r|r|r}
\hline \multicolumn{5}{c}{ Model Summary $^{\mathbf{b}}$} \\
\hline Model & $\mathrm{R}$ & R Square & $\begin{array}{c}\text { Adjusted R } \\
\text { Square }\end{array}$ & $\begin{array}{c}\text { Std. Error of } \\
\text { the Estimate }\end{array}$ \\
\hline 1 & $.701^{\mathrm{a}}$ & .492 & .461 & 3.682 \\
\hline
\end{tabular}

Based on the results in the table above obtained a correlation value of 0.701 . This shows that the Current ratio (X1) and Working capital turnover (X2) variables together have a strong degree of influence on Return on assets (Y).

\section{Analysis of the Coefficient of Determination}

Determination coefficient analysis is used to determine the magnitude of influence between independent variables on the dependent variable. The results of data processing can be explained as follows: 
Table 10.

Current Coefficient Determination Test Results on Return on assets

\begin{tabular}{ll|r|r|r}
\multicolumn{5}{c}{ Model Summary } \\
\hline Model & R & R Square & $\begin{array}{c}\text { Adjusted R } \\
\text { Square }\end{array}$ & $\begin{array}{c}\text { Std. Error of the } \\
\text { Estimate }\end{array}$ \\
\hline 1 & $.571^{\mathrm{a}}$ & .326 & .306 & 4.177 \\
\hline
\end{tabular}

Based on the results in the table above obtained $\mathrm{R}$ Square value of 0.326 . This shows that the contribution of the influence of the Current ratio partially on Return on assets is $32.6 \%$.

Table 11.

Results of Working Capital Turnover Determination Tests on Return on Assets

\section{Model Summary}

\begin{tabular}{ll|r|r|r}
\hline Model & R & R Square & \multicolumn{1}{c}{$\begin{array}{c}\text { Adjusted R } \\
\text { Square }\end{array}$} & $\begin{array}{c}\text { Std. Error of the } \\
\text { Estimate }\end{array}$ \\
\hline 1 & $.544^{\mathrm{a}}$ & .296 & .275 & 4.269 \\
\hline
\end{tabular}

Obtained an R Square value of 0.296. This shows that the effect of working capital turnover partially on Return on assets is $29.6 \%$.

Table 12.

Determination Coefficient Test Results Effect of Current Ratio and Working Capital Turnover Against Return on Assets

\section{Model Summary}

\begin{tabular}{ll|rrrr}
\hline Model & R & R Square & \multicolumn{2}{c}{$\begin{array}{c}\text { Adjusted R } \\
\text { Square }\end{array}$} & $\begin{array}{c}\text { Std. Error of the } \\
\text { Estimate }\end{array}$ \\
\hline 1 & $.701^{\mathrm{a}}$ & .492 & .461 & 3.682 \\
\hline
\end{tabular}

Based on the results in the table above obtained R Square value of 0.492 . This shows that the contribution of the influence of the current ratio partially on Return on assets is $49.2 \%$, while the remaining $50.8 \%$ is influenced by other factors.

\section{Hypotesis Test}

Hypothesis testing is intended to determine whether the hypothesis should be accepted or rejected. This test used the t-test (partial) and F test (simultaneous). Hypothesis testing partially in this study uses the t-test to test how the influence of each independent variable individually on the dependent variable.

Table 13.

Hypothesis Testing Current Variable Ratio of Return on Assets

\section{Coefficients $^{\mathrm{a}}$}

\begin{tabular}{|c|c|c|c|c|c|c|}
\hline \multirow{2}{*}{\multicolumn{2}{|c|}{ Model }} & \multicolumn{2}{|c|}{$\begin{array}{l}\text { Unstandardized } \\
\text { Coefficients }\end{array}$} & \multirow{2}{*}{$\begin{array}{c}\text { Standardized } \\
\text { Coefficients } \\
\text { Beta } \\
\end{array}$} & \multirow{2}{*}{$\mathrm{t}$} & \multirow[b]{2}{*}{ Sig. } \\
\hline & & B & Std. Error & & & \\
\hline \multirow[t]{2}{*}{1} & (Constant) & 26.112 & 9.009 & & 2.899 & .007 \\
\hline & Current Ratio (X1) & .921 & .227 & .571 & 4.055 & .000 \\
\hline
\end{tabular}


Obtained $\rho$ value $0,000<0.05$. Thus the first hypothesis states that there is a positive and significant influence between the Current ratio of Return on assets that can be accepted.

Table 14.

Hypothesis Testing Working Capital Turnover Variable Against Return on Assets

\begin{tabular}{|c|c|c|c|c|c|c|}
\hline \multicolumn{7}{|c|}{ Coefficients $^{\mathbf{a}}$} \\
\hline \multirow{2}{*}{\multicolumn{2}{|c|}{ Model }} & \multicolumn{2}{|c|}{$\begin{array}{c}\text { Unstandardized } \\
\text { Coefficients }\end{array}$} & \multirow{2}{*}{$\begin{array}{c}\text { Standardized } \\
\text { Coefficients } \\
\text { Beta } \\
\end{array}$} & \multirow[b]{2}{*}{$t$} & \multirow[b]{2}{*}{ Sig. } \\
\hline & & $\mathrm{B}$ & Std. Error & & & \\
\hline 1 & (Constant) & 31.333 & 8.285 & & 3.782 & .001 \\
\hline & Working Capital Turnover (X2) & .574 & .152 & .544 & 3.780 & .001 \\
\hline
\end{tabular}

Obtained $\rho$ value $0.001<0.05$. Thus the second hypothesis which states that there is a positive and significant influence between working capital turnover on return on assets can be accepted.

Hypothesis testing together is intended to determine the effect of all independent variables on the dependent variable namely the current ratio and working capital turnover on return on assets. In this test, the F-test is used.

Table 15.

Simultaneous Hypothesis Testing

\begin{tabular}{ll|r|r|r|r|r}
\multicolumn{7}{c}{ ANOVA $^{\mathbf{a}}$} \\
\hline \multicolumn{1}{l}{ Model } & Sum of Squares & df & Mean Square & \multicolumn{1}{c}{ F } & \multicolumn{1}{c}{ Sig. } \\
\hline \multirow{2}{*}{$1 \quad$ Regression } & 432.659 & 2 & 216.329 & 15.957 & $.000^{\mathrm{b}}$ \\
\cline { 2 - 7 } & Residual & 447.393 & 33 & 13.557 & & \\
\cline { 2 - 7 } & Total & 880.051 & 35 & & & \\
\hline
\end{tabular}

Based on the above data processing results obtained $\rho$ value $0,000<0.05$, there is a positive and significant effect between the current ratio and rorking capital turnover together on Return on assets can be accepted.

\section{CONCLUSION}

The results showed that the current ratio had a significant effect on return on assets. This can be seen from $\rho$ value $0,000<0.05$. The contribution of influence is $32.6 \%$. Working capital turnover has a significant effect on return on assets. This can be seen from $\rho$ value $0,000<0.05$. The contribution of influence is $29.6 \%$. The current ratio and working capital turnover together have a significant effect on return on assets. This can be seen $\rho$ value $0,000<0.05$. The contribution of influence is $49.2 \%$.

\section{REFERENCES}

Arimi, M., \& Mahfud, M. K. (2012). Analisis Faktor-Faktor yang Mempengaruhi Profitabilitas Perbankan. Diponegoro Journal of Management.

Baskara, I. G. K. (2013). Lembaga Keuangan Mikro di Indonesia. Buletin Studi Ekonomi.

Brigham, E. F., \& Houston, J. F. (2013). Dasar-Dasar Manajemen Keuangan. Salemba Empat. https://doi.org/10.1145/2505515.2507827

Butar, L. K. B., \& Sudarsi, S. (2012). Pengaruh Ukuran Perusahaan, Profitabilitas, Leverage, 
Dan Kepemilikan Institusional Terhadap Perataan Laba: Studi Empiris pada Perusahaan Food and Beverages yang Terdaftar di BEI. Dinamika Akuntansi, Keuangan dan Perbankan.

Ekawati, E. (2014). Manajemen Keuangan. Modul Kuliah. https://doi.org/10.1016/S00448486(98)00413-X

Faisal, A., Samben, R., \& Pattisahusiwa, S. (2018). Analisis kinerja keuangan. KINERJA. https://doi.org/10.29264/jkin.v14i1.2444

Gemilang, D. N. (2017). Pegaruh Likuiditas, Leverage, Profitabilitas, Ukuran Perusahaan dan Capital Intensity Terhadap Agresivitas Pajak Perusahaan (Studi Empiris pada Perusahaan Property dan Real Estate yang Terdaftar di BEI pada Tahun 2013-2015). Skripsi.

Gunawan, M., \& Linawati, N. (2013). Analisa Faktor yang Berhubungan dengan Pertimbangan Cost and Benefit Kartu Kredit. Finesta.

Habibah, M. (2015). Analisis Pengaruh Profitabilitas, Struktur Aset, Likuiditas, dan Pertumbuhan Penjualan terhadap Struktur Modal. Jurnal Ilmu \& Riset Akuntansi.

Hasibuan, N. (1993). Ekonomi Industri: Persaingan, Monopoli dan Regulasi. In LP3ES, Jakarta.

Heryono, H., \& Kardianawati, A. (2018). Implementasi Metode Naive Bayes Untuk Klasifikasi Kredit Motor. JOINS (Journal of Information System).

Horne, J.C. dan Wachowicz, J. M. (2007). Prinsip-Prinsip Manajemen Keuangan. In PrinsipPrinsip Manajemen Keuangan. https://doi.org/10.4324/9781315641348

Hutapea, L., \& Muningsih, E. (2017). Implementasi Informasi Pembayaran Kredit Berbasis Web (Studi Kasus: PT. Putra Asman Nainggolan Yogyakarta). Indonesian Journal od Network \& Security (IJNS).

Indradi, D. (2018). Pengaruh Likuiditas, Capital Intensity terhadap Agresivitas Pajak. Jurnal Akuntansi Berkelanjutan Indonesia.

Kasmir. (2014a). Bank dan Lembaga Kuangan Lainnya. In PT. Raja Grafindo Persada jakarta.

Kasmir. (2014b). Laporan Keuangan Bank. Manajemen Perbankan.

Kurnianingsih, H. T. (2013). Pengaruh Profitabilitas Dan Size Perusahaan Terhadap Corporate Social Responsibility. Jurnal Riset Akuntansi Dan Bisnis.

Kusumawardhani, I. (2018). Pengaruh Kondisi Keuangan, Financial Distres, Profitabilitas Dan Ukuran Perusahaan Terhadap Opini Audit Going Concern. Buletin Ekonomi.

Lestari, K. F., \& Tanuatmodjo, H. (2016). Pengaruh Likuiditas Dan Profitabilitas Terhadap Kebijakan Dividen. Journal of Business Management Education |.

Maulida, I. S., Moehaditoyo, S. H., \& Nugroho, M. (2018). Analisis Rasio Keuangan Untuk Memprediksi Financial Distress Pada Perusahaan Manufaktur Yang Terdaftar Di Bursa Efek Indonesia 2014-2016. Jurnal Ilmiah Administrasi Bisnis dan Inovasi. https://doi.org/10.25139/jai.v2i1.1149

Mulyanti, D., \& Supriyani, R. L. (2018). Pengaruh Perputaran Kas dan Perputaran Persediaan Terhadap Likuiditas pada PT Ultra Jaya, Tbk. Jurnal Kajian Ilmiah. https://doi.org/10.31599/jki.v18i1.180

Putri, N. W. K. A., \& Merkusiwati, N. K. L. A. (2014). Pengaruh Mekanisme Corporate 
Governance, Likuiditas, Leverage, Dan Ukuran Perusahaan Pada Financial Distress. EJurnal Akuntansi.

Ramona, S. (2017). Pengaruh Corporate Social Responsibility Terhadap Nilai Perusahaan Dengan Profitabilitas Sebagai Variabel Moderating (Studi Empiris Perusahaan Sektor Pertambangan yang Terdaftar di Bursa Efek Indonesia Periode 2011-2015). Jurnal Fakultas Ekonomi Prodi Akuntansi Universitas Pasir Pengaraian.

Rengifurwarin, Z. A., Akib, H., \& Salam, R. (2018). Snapshot of public service quality in the center for integrated business service (CIBS), cooperative micro small and medium enterprises (CMSME), Maluku Province, Indonesia. Journal of Entrepreneurship Education.

Setiadewi, K., \& Purbawangsa, I. (2015). Pengaruh Ukuran Perusahaan dan Leverage Terhadap Profitabilitas dan Nilai Perusahaan. E-Jurnal Manajemen Universitas Udayana.

Siamat, D. (2005). Manajemen Lembaga Keuangan. "Kebijakan Moneter dan Perbankan.” In Jakarta: Fakultas Ekonomi Universitas Indonesia, edisi kesatu. https://doi.org/10.1515/ci.2005.27.6.25

Sugiyono. (2016). Metode Penelitian dan Pengembangan (Research and Development/R\&D). In Bandung: Alfabeta. https://doi.org/10.1016/j.drudis.2010.11.005

Suharsimi, A. (2013). Prosedur Penelitian : Suatu Pendekatan Praktik (Edisi Revisi). Jakarta: Rineka Cipta. https://doi.org/10.1017/CBO9781107415324.004

Sunarsi, D. (2017). Pengaruh Kepemimpinan Dan Budaya Organisasi terhadap Kinerja Karyawan Pada Cabang Pembantu Bank DKI Pondok Labu - Jakarta Selatan. JENIUS, $1(2), 21$.

Sunarsi, D. (2018a). Pengaruh Gaya Kepemimpinan, Motivasi Dan Disiplin Kerja Terhadap Kinerja Pendidik Yayasan Marvin. Inovasi, 5(1), 1-18.

Sunarsi, D. (2018b). Pengaruh Gaya Kepemimpinan dan Disiplin Kerja Terhadap Kinerja Karyawan Pada CV. Usaha Mandiri Jakarta. JENIUS, 1(2).

Surya, S., Ruliana, R., \& Soetama, D. R. (2017). Pengaruh Perputaran Kas dan Perputaran Persediaan Terhadap Profitabilitas. Akuntabilitas. https://doi.org/10.15408/akt.v10i2.6139

Syaifuddin. (2008). Manajemen Keuangan (Teori dan aplikasi). 2008. https://doi.org/10.1017/CBO9781107415324.004

Tambunan, T. T., T, D. N. S., \& Arus, A. (2004). Kajian Persaingan Dalam Industri Retail. Kajian Persaingan Dalam Industri Ritel.

Utomo, T. J. (2011). Persaingan Bisnis Ritel: Tradisional vs Modern (The Competition of Retail Business : Traditional vs Modern). Fokus Ekonomi.

Yusra, I. (2016). Kemampuan Rasio Likuiditas dan Solvabilitas dalam Memprediksi Laba Perusahaan : Studi Empiris pada Perusahaan Telekomunikasi. jurnal Benefita. 